Britain is continuing in three series (Well Catalogue Series, Research Reports, and Hydrogeological Reports), and consideration is being given to a fourth series dealing with instrumental and similar matters. Publication of hydrogeological maps has also been started with the issue of that for North and East Lincolnshire and will be extended to cover the major ground-water provinces.

Overseas activities are now being undertaken by the Water Department for the first time and although the scale of the present programme is small, it is intended that this important aspect of overseas applied geology shall not be neglected.

D. A. Gray.

\author{
Institute of Geological Sciences, Water Department, \\ EXHIBITION ROAD, SOUTH KENSINGTON, \\ LONDON, S.W. 7. \\ 13th June, 1967.
}

\title{
PRE-CAMBRIAN AND LOWER PALAEOZOIC ROCKS OF CO. WEXFORD
}

SIR,- - In a recent paper (Geol. Mag., 104(3), 213-221, 1967) we quoted a note by J. W. Baker in the Welsh Geological Quarterly $(1(3), 17)$ in which he stated that the Rosslare Series and its metamorphisms were "pre-Ordovician and not Pre-Cambrian (as previously supposed)". A subsequent issue of the same Journal (1 (4), 14), issued after our paper had gone to press, contained an erratum to Baker's note : it should have read "the Rosslare Series and its metamorphism is Pre-Cambrian not Cambrian as previously supposed ". Baker and we, therefore, agree that the Rosslare Series $(=$ Rosslare Complex) is Pre-Cambrian.

\section{REFERENCES}

BAKER, J. W., 1966. The geology of south-east Co. Wexford, Eire. Welsh geol. Quart., 1 (3), 17.

Crimes, T. P., and N. B. Dhonau, 1967. The Pre-Cambrian and Lower Palaeozoic Rocks of south-east Co. Wexford, Eire, Geol. Mag., 104 (3), 213-221.

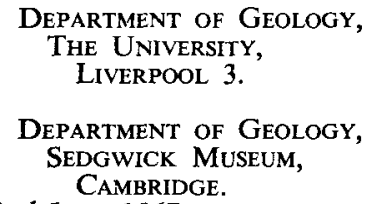

T. P. Crimes,

N. B. Dhonau,

\section{THE SILURO-DEVONIAN BOUNDARY}

SIR,--International agreement on the best horizon at which to draw the Siluro-Devonian boundary may be obtained at the International Symposium on the Silurian and Devonian at Leningrad in 1968. In view of the trend of opinion expressed in much recent literature it seems unlikely that the horizon selected will be at or even close to the horizon which has long been accepted as the Siluro-Devonian boundary in the Welsh Marches of Britain, the area where the Old Red System was first defined by Murchison. Indications are that a faunal horizon which will be correlated with some level near to the Downtonian/Dittonian boundary may well be agreed, and, if so, its application to this country will be essentially an academic palaeontological exercise. Historical justification for such a choice will be virtually non-existent, and this may be of little significance to the palaeontological argument, but a recent paper (Holland, 1965) and subsequent discussion of it (Tarlo, 1965) suggest 